\title{
Marzena Wysocka-Narewska
}

University of Silesia, Katowice

https://orcid.org/0000-0003-2787-8676

\section{Distance Learning in Polish Schools During the Coronavirus Lockdown: the Areas of Success and Failure Experienced by Polish Teachers of English as a FL}

\begin{abstract}
Based on Roblyer \& Edwards (2000: 192), distance learning means "the acquisition of knowledge and skills through mediated information and instruction, encompassing all technologies and other forms of learning at a distance." The instructional delivery includes an instructor who is physically located in a different place from the learner, as well as possibly providing instruction at disparate times. More specifically, the instructor controls the instructional sequencing and pacing and all learners participate in the same learning activities. The aim of the paper is to show the advantages and disadvantages of distance schooling during the Covid-19 lockdown, the emphasis being placed upon among others, the teacher - student relationship, the equipment conditions required for running an English lesson and working online, as well as some "food for thought" in the form of necessary changes and modifications to be introduced, which have been suggested by the sample in question. The respondents constitute 9 teachers from secondary schools, who have replied to an online questionnaire investigating the situation in Polish schools, concerning distance education, specifically teaching a FL. Apart from presenting the current state of affairs, some suggestions for the future are remarked upon.
\end{abstract}

K e y w o r d s: distance learning, areas of success and failure, solutions to problems 


\section{Distance learning}

Following Roblyer \& Edwards (2000: 192), distance learning is "the acquisition of knowledge and skills through mediated information and instruction, encompassing all technologies and other forms of learning at a distance". The instructional delivery includes an instructor who is physically located in a different place from the learner, as well as possibly providing instruction at disparate times. To be more specific, the instructor controls the instructional sequencing and pacing and all learners participate in the same learning activities.

\section{Types of distance learning}

Synchronous and asynchronous types of distance learning are the most basic and frequent in use (Taplin et al.2013). A synchronous online learning is based upon the cooperative participation of students in learning activities and requires them to be present at a given time. The tools used in this process involve online chats, videoconferences, live webcasting, application sharing, whiteboard, polling and virtual classrooms, as they enable participants and instructors to ask and answer questions in real-time. An asynchronous type of learning, on the other hand, is time independent (Young 2011). It allows students to create their own learning schedule and due to its flexibility is considered to be more student-centred. The teacher/student interaction is executed in different forms: virtual office hours, e-mails or "check-in" online conversations once a week or month. There is a whole range of tools used in asynchronous online learning: reading materials in PDF files, pre-recorded lectures, presentations, Google Drive for coordinated group projects, educational games, audio tapes and video (Taplin et al. 2013). A huge advantage is that students can always revise those materials in the case of uncertainty or any problematic issues.

Some more specific types include:

- Computer Managed Learning

- Computer Assisted Instruction

- Fixed E-learning

- Adaptive E-learning

- Linear E-learning

- Interactive Online learning 
Distance learning in Polish schools during the Coronavirus lockdown...

- Individual Online Learning

- Collaborative Online Learning

In CML, the main role of the computer is record-keeping without any direct instruction to the learner (Asterhan \&Schwarz 2011). It helps the teacher by means of taking over the responsibility of evaluating the students' response sheets, the gathering and sharing of information about each student, finding the resource options available for every individual student to learn a topic, monitoring the process of learning, and directing it. Computer Assisted Instruction (CAI), also sometimes referred to as computer-assisted learning (CAL), is another type of e-learning which uses computers together with traditional teaching. Computer-assisted training methods use a combination of multimedia such as text, graphics, sound, and video in order to enhance learning. The primary value of CAI is interactivity which allows students to become active learners instead of passive learners, by utilizing various methods such as quizzes and other computer-assisted teaching and testing mechanisms.

Following Graham (2006), the main characteristic of fixed e-learning is that it does not utilize the valuable real-time data gained from student inputs. The assumption is that analyzing each student individually through their data and making changes to the materials according to this data leads to better learning outcomes for all students. Examples of a fixed e-learning situation include lectures uploaded on sites like YouTube. Even though you can watch them any time you want, you are still restricted to whatever the teacher is describing in a particular lecture, and you have to follow along. Although it makes the actual teaching part easier for instructors because they just need to prepare one lesson at a time, this form severely disadvantages students who have different needs and would fare much better with a more adaptive system.

Accordingly, as Bonk \& Zhang (2006) insist, adaptive e-learning is an innovative type making it possible for a teacher to adapt and redesign learning materials for each individual learner. Taking a number of parameters such as student performance, goals, abilities, skills, and characteristics into consideration, adaptive e-learning tools allow education to become more individualized and student-centered.

Linear e-learning, based on Lehman \& Conceição (2011), relies on pedagogical strategies concerning program-centeredness. More specifically, it means that no two-way communication between teachers and students is allowed, and sending training materials to students through television and radio programs are classic examples of being in contact with each other. The situation changes drastically in the case of interactive online learning, allowing senders to become receivers and vice versa, effectively enabling a two-way communication channel between the parties involved. From the messages sent and received, the teachers and students 
can influence their teaching and learning methods. For this reason, this mode of e-learning is considerably more popular, as it guarantees teachers and students a good rapport and the possibility to communicate more freely with each other.

Individual e-learning, as Young (2011) claims, follows an individualized learning plan constituting a user-specific learning program or strategy that resembles a mapped academic plan, reflecting each learner's unique set of strengths, weaknesses, goals, needs, abilities, preferences, and interests. This type of learning is not ideal for developing communicational skills and teamwork abilities in students, as it largely focuses on students learning independently, without communication with other students.

Therefore, a more interesting and beneficial approach is that of collaboration and cooperation blended together. Harasim (2012) views collaborative online education as a learning model where students are stimulated and guided into working together in order to construct knowledge in an innovative way and look for the conceptual knowledge necessary for the solution of a given problem. In most cases, it consists only in providing digital content, online self-assessment tests, or the simple exchange of information, there is hardly any online tutoring or collaborative activities (which are an integral part of the instructional design) involving intensive online interactions. Simply put, collaborative online learning provokes students' activeness and involvement while the online tutor plays a key role, not only as part of the community, but also as a link between the learning community and knowledge about the particular subject.

\section{Organization of distance learning}

The implementation of remote teaching is a form of pedagogical innovation (Rozporządzenie Ministerstwa Edukacji, 2002 [Ordinance of the Ministry of Education, 2002]) containing modern solutions with regard to the curriculum, organization or methodology aimed at increasing the creativity and entrepreneurship of students (Ustawa z dnia 14 grudnia 2016 r. Prawo oświatowe, 2016 [Act of 14 December 2016. Educational Law]).

Wedeł-Domaradzka and Raczyńska (2013) list a number of implementation principles concerning distance learning. Among them, the following recommendations addressed to teachers can be distinguished:

- Distance learning requires a transformation and adaptation of the existing resources and methods to the new learning environment as well as a change in one's own habits. 
Distance learning in Polish schools during the Coronavirus lockdown...

- Education changes the activity of both the teacher and the student. The teacher should be more motivated and focus on encouraging pupils.

- In the educational process, the use of diverse media is desirable because of the need to diversify resources. They are selected according to the educational situation and type of the audience.

- The teacher's competencies that are important in distance education include those related to technical and IT matters, instructive, content-related, legal and moral ("netiquette") ones and those related to self-development.

As can be seen, the requirements of remote education translate into a considerable organizational effort, starting with the implementation of procedures and many logistical activities to teacher's readiness (including above all the ability to use information and communication technologies and learning resources), and learner support in the form of necessary equipment and the Internet, to name a few.

\section{Organization of distance learning in Poland}

In order to minimize the negative effects of the pandemic situation, a form of distance teaching was implemented in Polish schools on 25 March 2020 (Rozporządzenie Ministerstwa Edukacji, 2020 [Ordinance of the Ministry of Education, 2020]). The responsibilities of the head of the school were defined, involving teachers, students and their parents. Among others, the head of the institution was obliged to organize distance learning for students. Additionally, what was regulated, as Godawa (2020) enumerates, involved the weekly content of teaching taking into account:

a) placing an equal burden of work on each pupil on particular days of the week

b) the diversity of classes on each day;

c) pupils' different mental and physical abilities to make intensive mental effort during the day;

d) the need to alternate teaching with and without the use of screen monitors; and

e) limitations related to the specificity of remote classes (Rozporządzenie Ministerstwa Edukacji, 2020, § 1, s. 3 [Ordinance of the Ministry of Education, 2020, $\S 1$, p. 3]).

In addition to the guidelines on how to start and develop distance learning, the instruction includes a list of e-tools and e-materials to be used in remote work with learners. Apart from the guidelines for the organisers of the process of education, the regulations contain information and recommendations addressed to learners and their parents saying that "in the current situation, learning at home is a neces- 
sity. However, it must be borne in mind that this special time should be devoted not only to learning but also to developing the child's passions and interests, as well as resting and strengthening family relationships" (Ministry of Education, 2020: 16). A diversity of tasks and the importance of the objectives placed distance learning among one of the most important undertakings that Polish society, especially schools and families, were to face.

The advantages and disadvantages of the Covid-19 distance learning in Poland have already been of interest to many researchers. The latest studies by Godawa (2020) and Nalaskowski (2021) brought to light diverse descriptions of chaos in schools and various social inequalities being observed among the learners. Less attention was paid to the stabilization period, including areas of adaptation to the unusual situation.

\section{Methodology of own research}

The present study has been structured in a more detailed way to investigate both the exact scope of the difficulties, type of obstacles as well as the conditions experienced and coped with apparent ease by the teaching staff during the first lockdown period in Polish schools.

\section{The sample description}

The subjects constituted 9 teachers affiliated with three secondary schools in Będzin (Poland), namely I, II and III LO.

Table 1

Sample description

\begin{tabular}{|c|c|c|c|c|c|c|c|c|c|}
\hline Category & $\mathrm{T} 1$ & $\mathrm{~T} 2$ & T3 & $\mathrm{T} 4$ & T5 & T6 & T7 & T8 & T9 \\
\hline Gender & $\mathrm{F}$ & $\mathrm{F}$ & $\mathrm{F}$ & $\mathrm{F}$ & $\mathrm{F}$ & $F$ & $\mathrm{~F}$ & $\mathrm{~F}$ & $\mathrm{~F}$ \\
\hline Age & 29 & 33 & 33 & 49 & 56 & 31 & 38 & 38 & 41 \\
\hline $\begin{array}{l}\text { Education } \\
\text { \& subject } \\
\text { taugh }\end{array}$ & $\begin{array}{l}\text { English } \\
\text { MA }\end{array}$ & $\begin{array}{l}\text { English } \\
\text { MA }\end{array}$ & $\begin{array}{l}\text { English } \\
\text { MA }\end{array}$ & $\begin{array}{l}\text { English } \\
\text { MA }\end{array}$ & $\begin{array}{l}\text { English } \\
\text { MA }\end{array}$ & $\begin{array}{l}\text { English } \\
\mathrm{MA}\end{array}$ & $\begin{array}{l}\text { English } \\
\text { MA }\end{array}$ & $\begin{array}{l}\text { English } \\
\text { (MA) }\end{array}$ & $\begin{array}{l}\text { English } \\
\text { MA }\end{array}$ \\
\hline
\end{tabular}


Distance learning in Polish schools during the Coronavirus lockdown...

\begin{tabular}{llllllllll}
\hline $\begin{array}{l}\text { Teaching } \\
\text { experience }\end{array}$ & 5 & 10 & 11 & 25 & 30 & 7 & 15 & 14 & 15 \\
\hline $\begin{array}{l}\text { Type } \\
\text { of on-line } \\
\text { teaching }\end{array}$ & $\mathrm{S}$ & $\mathrm{S}$ & $\mathrm{S}$ & $\mathrm{S}$ & $\mathrm{S}$ & $\mathrm{S}$ & $\mathrm{S}$ & $\mathrm{S}$ & $\mathrm{S}$ \\
\hline
\end{tabular}

As seen from the table, the teachers invited to take part in the study are all female, between 29 and 56 years old. They have the necessary qualifications to teach English (MA), and teaching experience ranging from 5 to 30 years. Currently, all of them are engaged in a synchronous online teaching.

\section{The tool}

In order to collect the information evaluating online teaching in the schools under investigation, the online questionnaire was prepared and distributed among teachers. It consisted of a background section (gender, age, education, teaching experience, type of online teaching conducted and command of English), and the main part divided into three sub-sections (teacher-student rapport, type of material taught, and (non)problematic issues). The first of them involved general behavior and student actions typical of a lesson, such as:

- Netiquette,

- Punctuality.

- Active participation in the lesson: being prepared for the lesson, having homework done,

- Answers given and questions asked to the teacher,

- Volunteering to do a task, and

- Following teacher instructions.

The second list of entries consisted of both language skills and language subsystems, namely:

- Pronunciation,

- Reading,

- Writing,

- Listening,

- Speaking,

- Grammar, and

- Vocabulary 
Both parts were organized with the use of a 5-point frequency scale, and, additionally, a blank space was left for comments.

Finally, the third sub-section, which was open-ended in form, investigated the most and least problematic issues, as well as situations described as a feeling of success. Here, the subjects were asked to enumerate three in each category, and justify their choice.

\section{The study results}

Teacher 1 - has been teaching English for 5 years, and is fairly satisfied with her language quality. Her online teaching is synchronous and involves only third grade students. Despite the fact that these are the last school year classes, she faces a lot of difficulties. First and foremost, she complains about students' lack of punctuality, both with reference to lesson and break time, which is a daily routine and almost epidemic in nature. Secondly, the teacher observes lack of homework assignments very frequently, and students 'unwillingness to interact with her during lessons. The material covered, as she reports, is well-balanced, and does not cause any problems. The final section portrayed the students' negligence as a major weakness, and the material coverage as a successful achievement in the current situation.

Teacher 2 - has been working as an English teacher for 10 years, and assesses her command of English in a positive way. The biggest problems she mentions in her online teaching (done synchronously) relate to students' passivity in the classes. They neither answer nor ask any questions, and, even worse, do not follow the teacher's instructions. When it comes to the scope of the language taught, the teacher makes an attempt to cover all the necessary materials including both language skills and subsystems irrespective of the group age, though with a dose of an unenthusiastic attitude on the part of the students.

Teacher 3 - has been an English teacher for 11 years now, very much satisfied with her language proficiency. The classes she teaches on a regular basis range from first to third graders which suffer from a lot of problems in the pandemic situation. The biggest challenge for the teacher is to engage students into the 45 minutes of an online synchronous lesson, and, even harder, to encourage them to speak. As she writes in the questionnaire, the learners remain silent regardless of the lesson phase, topics covered, and extra materials offered. As practicing pronunciation and speaking is almost impossible, the teacher, trying to overcome difficulties, has made an incentive to carry out a written project in each of the 
Distance learning in Polish schools during the Coronavirus lockdown...

class, and, thanks to that, she can "see the light at the end of the tunnel, and hope of the way out of this crisis".

Teacher 4 - has been teaching English for 25 years and feels comfortable whenever using the language. Despite her long professional experience, she complains about the synchronous online education in many respects. What she has major difficulty in includes the whole process of instruction, starting from the application use, material distribution and classroom management. The students themselves seem to pose too many problems for the teacher. The most troublesome situations are very unwilling and succinct replies on the part of the students, lack of student volunteers, and a vast majority of late comers. When asked about the syllabus coverage, she admits doing just the bare minimum. Partly because, as she says, "there are still TEAMS operating difficulties, and partly due to the students' lack of interest or even their indifference".

Teacher 5 - is most experienced of all teachers included in the study as her teaching experience is 30 years. At the same time, she is very much confident about her English, which may be the result of her professional status and teaching career, including areas of success such as language Olympian students. She seems to be very positive about online teaching and, as she points out in the questionnaire, that she cannot think of either troublesome or passive students, and denies that any other examples of misbehavior exist. As far as the language introduced, practiced and produced in the lesson is concerned, everything is well-balanced to cater for the learners' needs, which translates into their ease in expression, and many volunteers on many occasions during the lesson. Simply put, each class the teacher "enters into" (she teaches 9 classes at school), is considered non-problematic and there is no room for failure whatsoever.

Teacher 6 - has been working as an English teacher for 7 years, and considers herself very enthusiastic about teaching. As eager to teach all her classes as she is, she still experiences a multitude of problems, ranging from disciplining students in the classroom to a broadly-understood evaluation. These have become even more a pain in the neck since the beginning of the pandemic situation and remote teaching. Once online teaching was introduced, the teacher complained about a bit too monotonous lessons caused largely by the too slow pace. Conversely, she is fairly satisfied with the lesson content, notably language being provided to the students in line with sufficient practice and production.

Teachers 7,8 and 9 are grouped and described here together as their questionnaire data overlapped to a great extent. The first thing they share is their teaching experience, i.e., 15, 14 and 15 respectively. The second one includes a very positive attitude towards their English skills, and online classes. Such an optimistic point of view translates into successful lessons conducted synchronously with the first, second and third graders (each of the teachers in question). The teachers neither 
complain about any forms of learners' misbehavior nor the structure/ content of the lessons. On the contrary, they enumerate a few characteristic features and/or conditions of a positive teacher-student rapport during online instruction:

- If you are always on time, even those late comers try to be punctual.

- If you do not hurry up students, they become volunteers.

- If you do not punish students for lack of homework, they do it eagerly.

- If you practice all language skills, students believe it is possible.

- If you have Internet connection problems, do not panic, / take it easy/ try to make fun of it.

- If your students have Internet connection problems, try to help them, using telephone/messenger communication instead.

- If your students do not want to show up, do not force them.

- If you or your students have family members around/ in the background, do not feel sorry / ashamed of/ and just continue sharing attention.

The above-mentioned statements seem to constitute a set of golden rules guaranteeing a successful organization and realization of teaching goals. No drawbacks or inconveniences were experienced by these teachers whatsoever.

\section{Summary of the results}

Based on the findings that emerged in the study, both areas of failure and success in distance education can be distinguished. The most frequent ones include the following:

Table 2

Areas of failure and success

\begin{tabular}{|c|c|}
\hline FAILURE & SUCCESS \\
\hline T1. STUDENT BEHAVIOUR & T1. MATERIAL COVERED \\
\hline T2. STUDENT BEHAVIOUR & T2. MATERIAL COVERED \\
\hline T3. SPEAKING PRACTICE & T3. WRITTEN PRACTICE \\
\hline $\begin{array}{l}\text { T4. APPLICATION USE, SYLLABUS COVERAGE, } \\
\text { STUDENT BEHAVIOUR }\end{array}$ & T4. --------- \\
\hline T5. ------------- & T5. .................. \\
\hline T6. CLASSROOM MANAGEMENT, EVALUATION & T6. MATERIAL COVERED \\
\hline T7. --------------- & T7. EVERYTHING \\
\hline T8. ...................... & T8. EVERYTHING \\
\hline T9. ...................... & T9. EVERYTHING \\
\hline
\end{tabular}


Distance learning in Polish schools during the Coronavirus lockdown...

Generally speaking, 6 out of 9 respondents have expressed both their ideas for improvement and/or change (failure section), as well as the ones that do not require either intervention or interference as such (success section). The remaining three teachers show a complacent attitude towards the process of distance education, claiming that "everything is a success."

\section{Concluding remarks}

Based on the data collected, a few conclusions can be drawn:

Firstly, the respondents' attitude towards distance learning was not dependent on their age, education and/or professional experience. It was rather influenced by some managerial and soft skills that are synonymous with appropriate contextual, interpersonal and behavioural competences. More specifically, as we read in Rao (2010), they are the skills and abilities that are essential to communicate with superiors, peers, subordinates, clients and vendors. These are the skills related to both verbal and non-verbal language for effective and efficient communication.

Secondly, the areas of failure and success seem to appear with similar frequency, though the former being wider in scope than the latter. Accordingly, most failures are reported to be associated with the lack of teacher-student cooperation, and problems with covering the material. Successful situations, on the other hand, reflect teachers' satisfaction with the process of imparting information.

Thirdly, some solutions to teachers' problems might be offered. These can be divided into two stages, namely, the teacher training period, and the teaching proper/career phase.

\section{Implications and solutions to problems}

As far as the first stage is concerned, it is advisable to incorporate the subject/ course of soft skills into the teaching programme, or, if proven to be impossible, at least a few activities promoting skill development. Following Rao (2010), we can teach the skills in question by means of:

- teaching empathy

Here, a good idea will be situations/exercises asking the students what would you do if..., 
- dejargonising language

This step consists in preparing a series of activities requiring the students to use the exact language expression or a list of them in a conversation, and

- using a sense of humor

The teachers are advised to use stories, ask students to finish, to begin or to create stories on their own.

Another suggestion during teacher training could be that put forward by Jedliński (2008) who proposes a soft skill training consisting in role playing. This could be best done by means of videotaping, allowing the students to replay and recognize who's who, change and strive for the desired behaviour. Apart from observations, it could also serve as a source of feedback teachers give to soften students' reactions whenever necessary, not only to increase their role, but also the role of soft skills in language learning.

When it comes to the second stage, it would be of great importance if teachers could make use of the previously-mentioned exercises and introduce them into their own classrooms. Some other solutions to the problems highlighted by the sample of the study might range from the courses currently offered by many institutions (e.g., the course devoted to distance learning https://www.ntg.pl/szkolenia/ szkolenia-biurowe/ms-office-on-line/655-o365-ms-teams-praca-w-szkole-kursdlanauczycieli), IT support offered by schools (in the form of the IT staff available to teachers at the time of their working hours, to information/experience sharing forums (e.g., Facebook groups).

And, last but not least, it is always worth remembering that: "Success is not final; failure is not fatal: It is the courage to continue that counts." (Winston Churchil).

\section{References}

Asterhan, C. S. C., \& Schwarz, B. B. (2010). Online moderation of synchronous argumentation. International Journal of Computer-Supported Collaborative Learning, 5(3), 259-282.

Bonk, C., \& Zhang, K. (2006). Introducing the R2D2 model: Online learning for the diverse learners of this world. Distance Education, 27(2), 249-264.

Fatima, P., \& Hameed, M. (2020). Learner-Centred Language Learning Strategy in Digital Environment: Its Effect to Students' Vocabulary, Collaboration and Independence, TESOL International Journal, 15(4), 61-72.

Godawa, G. (2020). Wymuszona konieczna niedogodność - zdalne nauczanie w sytuacji pandemii COVID-19 w refleksji rodziców. Konteksty Pedagogiczne, 2(15), 207-225. 
Distance learning in Polish schools during the Coronavirus lockdown...

Graham, C. R. (2006). Blended learning systems: definition, current trends, and future directions. In Curtis J. Bonk, \& Ch. R. Graham (Eds.), The Handbook of blended learning: Global perspectives, local designs (pp. 203-210). San Francisco: Pfeiffer Publishing.

Harasim, L. (2012). Learning theory and online technologies. New York: Routledge/Taylor \& Francis.

Jedliński, K. (2008). Trening interpersonalny. Warszawa: W. A. B.

Jin, L., \& Xu, Y., Deifell, E., Angus, K. (2021). Emergency Remote Language Teaching and U.S.-Based College-Level World Language Educators' Intention to Adopt Online Teaching in Postpandemic Times. The Modern Language Journal, 105(2), 412-434.

Lehman, R. M., \& Conceição, S.C.O. (2010). Creating a sense of presence in online teaching: How to "be there" for distance learners. San Francisco: JosseyBass.

Makarova, E., \& Makarova, E. (2021). Blending pedagogy and digital technology to transform educational environment. International Journal of Cognitive Research in Science Engineering and Education, 6(2), 57-65.

Malik, M., \& Fatima, G, (2017). E-Learning: Students' Perspectives about Asynchronous and Synchronous Resources at Higher Education Level. Bulletin of Education and Research, 39(2), 183-195.

Ministerstwo Edukacji Narodowej (2020). Kształcenie na odległość. Poradnik dla szkół https://dokumenty.men.gov.pl/Ksztalcenie_na_odleglosc_\%E2\%80\%93_poradnik_dla_szkol [Ministry of Education (2020). Distance Learning. Handbook for Schools] https://dokumenty.men.gov. pl/Ksztalcenie_na_odleglosc_\%E2\%80\%93_poradnik_dla_szkol

Rao, M. S. 2010. Soft skills. Enhancing employability. Connecting campus with corporate. New Delhi: I.K. International Publishing House.

Roblyer, M.D., \& Edwards, J, Havriluk, M, A. (2000). Integrating educational technology into teaching. New Jersey: Prentice Hall.

Rozporządzenie Ministra Edukacji Narodowej i Sportu z dnia 9 kwietnia 2002 r. w sprawie warunków prowadzenia działalności innowacyjnej i eksperymentalnej przez publiczne szkoły i placówki [Ordinance of the Minister of National Education and Sport of 9 April 2002 on the Conditions for Innovative and Experimental Activities by Public Schools and Institutions]. https:/www.portaloswiatowy.pl/ksztalcenie-i-wychowanie/rozporzadzenie-ministra-edukacjinarodowej-i-sportu-z-9-kwietnia-2002-r.-w-sprawie-warunkow-prowadzenia-dzialalnosciinnowacyjnej-i-eksperymentalnej-przez-publiczne-szkoly-i-placowki.-dz.u.-z-2002-r.-nr-56poz.-506-11189.html

Rozporządzenie MEN z dnia 20 marca 2020 r. w sprawie szczególnych rozwiązań w okresie czasowego ograniczenia funkcjonowania jednostek systemu oświaty w związku z zapobieganiem, przeciwdziałaniem i zwalczaniem COVID-19. [Ordinance of the Ministry of Education of 20 March 2020 on Special Solutions in the Period of Temporary Limitation of the Functioning of Units of the Educational System in Connection with Preventing, Counteracting and Combating COVID-19] https://kuratorium.katowice.pl/wp-content/uploads/2020/03/rozporzadzenie-wsprawie-szczegolnych-rozwiazan-ar_t.-30c.pdf

Rozporządzenie Ministra Zdrowia z dnia 20 marca 2020 r. w sprawie ogłoszenia na obszarze Rzeczypospolitej Polskiej stanu epidemii. [Ordinance of the Minister of Health of 20 March 2020 on the Announcement of the State of the Epidemic on the Territory of the Republic of Poland] https://sip.lex.pl/akty-prawne/dzu-dziennik-ustaw/ogloszenie-na-obszarze-rzeczypospolitejpolskiej-stanu-epidemii-18972567

Smal, T. (2009). Nauczanie na odległość (e-learning). Zeszyty Naukowe WSOW, 3(153), 105-114. 
Taplin, R. H., Kerr, R., \& Brown, A. M. (2013). Who pays for blended learning? A cost-benefit analysis. The Internet and Higher Education, 18, 61-68.

Ustawa z dnia 14 grudnia 2016 r. Prawo oświatowe [Act of 14 December 2016. Educational Law], art. 1, p. 18 (Dz.U. z 2019 r. poz. 1148).

Wedeł-Domaradzka, A. \& Raczyńska, A. (2013). Jak skutecznie prowadzić zajęcia na platformie edukacyjnej? Poradnik. Warszawa: Krajowy Ośrodek Wspierania Edukacji Zawodowej i Ustawicznej.

Wysocka, M.S. (2012). The role of soft-skills in FL learning, Linguistica Silesiana 33, 257-268.

Young, J. R. (2011). College presidents are bullish on online education but face a skeptical public.

The Chronicle of Higher Education. http://chronicle.com/article/College-Presidents-AreBullish/128814/

Marzena Wysocka-Narewska

\title{
Nauka na odległość w polskich szkołach w okresie lockdownu: sukcesy i porażki w doświadczeniach nauczycieli języka angielskiego jako obcego
}

\author{
Streszczenie
}

Celem podjętych badań kwestionariuszowych jest rozeznanie w sytuacji, w jakiej znaleźli się nauczyciele pracujący w polskich szkołach w okresie lockdownu. Chodzi o nauczycieli języka angielskiego jako obcego pracujących z młodzieżą licealną i szeroko rozumianą naukę na odległość. W badaniu wzięło udział 9 nauczycieli z trzech szkół (I, II i III LO w Będzinie). Zakres pytań, na które odpowiedzieli za pośrednictwem ankiety dotyczył dwu obszarów - organizacji i zarządzania klasą oraz realizacji materiału językowego podczas lekcji online. Ankietowani, oprócz swych sukcesów przedstawili również trudności w pracy, z którymi borykają się na co dzień. W celu zaradzenia problemom nauczycieli Autorka prezentuje kilka z możliwych rozwiązań, takich jak rozwój osobowy (poprzez np. umiejętności miękkie), udział w kursach obsługi aplikacji internetowej, z której korzystają czy dyskusje na forach.

Słow a kluczowe: nauka na odległość, sukcesy i porażki, propozycje rozwiązania problemów 
Distance learning in Polish schools during the Coronavirus lockdown...

Мажена Высоцка-Нарэвска

\title{
Дистанционное обучение в польских школах в период локдауна: успехи и неудачи в опыте преподавателей английского языка как иностранного
}

\begin{abstract}
Аннно т ация
Целью проведенного анкетного исследования является определение положения учителей, работающих в польских школах в период локдауна. Речь идет об учителях английского языка как иностранного, работающих со старшеклассниками, и о широко понимаемом дистанционном обучении. В исследовании приняли участие девять учителей из трех школ (Средняя школа I, II и III в Бендзине). Диапазон вопросов, на которые они ответили в ходе опроса, касался двух областей - организации и управления классом, а также использования языковых материалов во время онлайн-уроков. Респонденты, помимо своих успехов, также рассказали о трудностях на работе, с которыми они борются ежедневно. Чтобы справиться с проблемами учителей, автор предлагает несколько возможных решений, таких как личностное развитие (например, с помощью soft skills), участие в курсах по использованию интернет-приложения, которое они применяют, или обсуждения на форумах.
\end{abstract}

К л ю ч е в ы е с ло в а: дистанционное обучение, успехи и неудачи, предложения по решению проблем.

Marzena Wysocka-Narewska

\section{El aprendizaje a distancia en las escuelas polacas durante el período de bloqueo: éxitos y fracasos en la experiencia de los profesores de inglés como lengua extranjera}

\author{
Resumen
}

El objetivo de la investigación del cuestionario realizada es identificar la situación de los profesores que trabajan en las escuelas polacas durante el período de cierre. Se trata de profesores de inglés como lengua extranjera que trabajan con estudiantes de secundaria y de un aprendizaje a distancia ampliamente comprendido. Nueve profesores de tres escuelas (High School I, II y III en Będzin) participaron en el estudio. La gama de preguntas que respondieron a través de la encuesta se refería a dos áreas: la organización y gestión del aula, y la implementación de material lingüístico durante las lecciones en línea. Los encuestados, además de sus éxitos, también presentaron las dificultades en el trabajo con las que luchan a diario. Para abordar los problemas de los docentes, el autor presenta varias posibles soluciones, como el desarrollo personal (a través, por ejemplo, de las habilidades blandas), la participación en cursos sobre el uso de la aplicación de Internet que utilizan o las discusiones en foros.

Pa labras clave: aprendizaje a distancia, éxitos y fracasos, sugerencias para la resolución de problemas. 